DOI https://doi.org/10.30525/978-9934-26-073-5-2-58

\title{
АКТУАЛЬНІ ПИТАННЯ СОЦІОКОМУНІКАТИВНОЇ АДАПТАЦІї ІНОЗЕМНИХ СТУДЕНТІВ ДО ОСВІТНЬОГО ПРОСТОРУ СУЧАСНОГО ЗВО
}

\author{
Кобиліна Ю. М. \\ старший викладач кафедри слов 'янської філології і журналістики \\ Таврійського національного університету імені В. І. Вернадського \\ м. Київ, Украӥна
}

У сучасних умовах міжнародного обміну в галузі освіти, науки i культури питання соціокомунікативної адаптації іноземних студентів набуває особливої актуальності. Комунікативна взаємодія іноземних студентів у новому для них освітньому просторі супроводжується складним процесом координації відносин іноземних студентів і соціокультурного середовища ЗВО загалом, в якому їм слід подолати різного роду соціально-моральні, психолінгвістичні, комунікативні бар'єри, освоїти нові види діяльності та форми поведінки.

Основними труднощами в соціокомунікативній адаптації іноземних студентів варто виокремити:

- особистісно-психологічні труднощі, пов'язані з пристосуванням особистості, зміною географічно-кліматичних умов, психоемоційним напруженням, що призводить до погіршення самопочуття, підвищення тривожності та напруженості;

- навчально-пізнавальні труднощі, пов'язані, в першу чергу, 3 недостатньою мовною підготовкою, подоланням відмінностей в системах освіти; адаптацією до нових вимог і системи контролю знань; організацією навчального процесу, який повинен будуватися на принципах саморозвитку особистості, розвитку навичок самостійної роботи;

- соціокультурні труднощі, пов'язані з освоєнням нового соціального і культурного простору 3ВО; подоланням мовного бар'єру в рішенні комунікативних проблем як з адміністрацією факультету, викладачами та співробітниками, так і в процесі міжособистісного спілкування всередині міжнаціональної малої навчальної групи, де труднощі проявляються у формі вираженої відчуженості від колективу навчальної групи, внутрішньо особистісні та міжособистісними конфліктами i, як наслідок, зниженням успішності, втратою інтересу і сенсу навчально-професійної діяльності [3]. 
У процесі професійної комунікації студенти-іноземці одночасно перебувають в трьох соціокультурних системах, які можуть як гальмувати, так і сприяти успішній адаптації: монокультурна система дружні зв'язки 3 іншими студентами того ж етносу (можливість висловлювати і показувати свої етнічні та культурні цінності землякам); бікультурна система - зв'язки між іноземцями та студентами, викладачами i офіційними особами держави (організація і функціонування навчально-виховного середовища студентів-іноземців); мультикультурна система - складається 3 друзів і знайомих різних національностей (створення компанії для відпочинку та розваг) [2].

Загалом етапи соціокомунікативної адаптації іноземних студентів до нового освітнього середовищі можна представити у вигляді низки взаємопов'язаних складових: входження в студентське середовище; засвоєння основних норм міжнародного колективу, вироблення власного стилю поведінки; формування стійкого позитивного ставлення до майбутньої професії, подолання «мовного бар'єру», посилення почуття академічного рівноправності. Чинниками такого процесу виступають: сприйняття нового середовища; ступінь інтеграції особистості (групи) в нове соціокультурне середовище; соціальне самопочуття та позитивне сприйняття іноземного студента іншими студентами [6].

На підставі цих факторів можна виокремити основні параметри соціокомунікативної адаптації: рівень володіння мовою країни навчання, вік, стать, прогнозовані результати, сподівання, контингент з яким стикається студент-іноземець, попередній досвід перебування в іншій культурі, ступінь комунікативних навичок. Найважче студентам-іноземцям вдається налаштуватися на нове соціальне середовище; необхідність розмовляти українською мовою; наявність проблеми двомовності в Україні, що ускладнює вивчення української мови; відсутність поруч рідних та друзів; нові умови проживання, пристосування до етнографічних та кліматичних змін; ставлення оточуючих; відмінність традиційних культурних зв'язків.

Подолання цих труднощів зумовить успішність процесу адаптації, що дозволить забезпечити адекватну взаємодію іноземних студентів 3 соціокультурним та інтелектуальним середовищем ЗВО, психоемоційну стабільність, формування нових якостей особистості і сприятливого соціального статусу, освоєння нових соціальних ролей, придбання нових цінностей, осмислення значущості традицій майбутньої професії. Ключову роль у цьому відводиться вивченню мови приймаючої країни, яка відкриває інше системне сприйняття, дозволяє порівнювати спосіб життя, мислення, діяльність та спілкування людей інших культур, 
збагачуючи новими знаннями і досвідом спілкування, взаємодіючи 3 новим соціокультурним середовищем [1].

Зміст діяльності щодо забезпечення успішної адаптації іноземних студентів в новому освітньому просторі включає основні напрямки:

1. Організаційно-методичне та інформаційне супроводження освітнього процесу передбачає: організацію, координацію діяльності всіх структурних підрозділів ЗВО з планування роботи, їі аналізу і корекції; актуалізацію інформації на сайті, створення і поширення інформаційних матеріалів, які відображають зміст, напрямок і форми життєдіяльності студентської молоді ЗВО; створення умов для ознайомлення студентів із специфікою навчального процесу.

2. Мовна адаптація іноземних студентів передбачає: використання системи викладання української мови як іноземної; забезпечення умов для проведення додаткових занять для іноземних студентів; роботу волонтерів з числа іноземних студентів старших курсів чи викладачів, що сприяє оптимізації взаємодії студентів 3 учасниками освітнього процесу (викладачами, студентами).

3. Соціально-педагогічний та психологічний супровід процесу адаптації іноземних студентів сприяє: забезпеченню соціальних гарантій; розвитку системи морального і матеріального заохочення; профілактиці тривожних станів дезадаптації («телефон довіри», інтернет-ресурс, тренінги і практикуми, індивідуальне та групове консультування тощо); сприяння в професійній адаптації іноземних студентів.

4. Культурно-особистісна діяльність студентів включає: створення умов для участі студентів у культурному житті ЗВО; залучення студентів до обговорення актуальних питань університетського життя; включення в різноманітні заходи суспільно-корисної, творчої, художньої, спортивної та іншої спрямованості.

Таким чином, соціокомунікативна адаптація іноземних студентів має складний i суперечливий характер, обумовлений впливом індивідуальних (індивідуальні характеристики, обставини життєвого досвіду індивіда) і групових (ступінь подібності або відмінності між культурами, особливо країни перебування; психологічні чинники адаптації до навчальної групи) факторів. Серед основних проблем соціокомунікативної адаптації слід виокремити: індивідуальні зміни статусу студента-іноземця (адаптація до незвичного соціокультурного оточення); загальні для будь-якого першокурсника (відповідність вимогам вищої школи), ускладнені іноземним походженням; загальні для молоді на даному віковому етапі; нові адаптивні, зумовлені етнічним (країна походження студента) статусом в іншій країні. 


\section{Література:}

1. Бондаренко, Л. М. Складності адаптації іноземних студентів до навчання в українських закладах вищої освіти / Л. М. Бондаренко, O. I. Артьомова // Науковий часопис Національного педагогічного університету імені М. П. Драгоманова. Серія 5: Педагогічні науки: реалії та перспективи: зб. наук. праць. Київ: Вид-во НПУ імені М. П. Драгоманова, 2019. Вип. 67. С. 33-37.

2. Довгодько Т. Адаптація іноземних студентів до освітнього середовища України / Т. Довгодько // Педагогіка і психологія професійної освіти. 2013. № 2. C. 114-120. URL: http://nbuv.gov.ua/UJRN/ Pippo_2013_2_15

3. Моргунова Н. Р. Форми та засоби соціокультурної адаптації іноземних студентів до умов навчання в Україні: практичний аспект реалізації / Н. Р. Моргунова // Новий Колегіум. 2014. - № 4. С. 35-39. URL: http://nbuv.gov.ua/UJRN/NovKol_2014_4_11

4. Ременцов А.Н. Социокультурные аспекты адаптации иностранных студентов / А.Н.Ременцов, А.А.Казанцева // Alma Mater (Вестник высшей школы). 2011. № 7. С. 10-14.

5. Спіріна Т. П., Зарюгіна Ю. Є. Особливості адаптації студентівпершокурсників до умов навчання у вищому навчальному закладі. Науковий вісник Ужгородського національного університету. 2014. Вип. 32. С. $182-184$

6. Стрельцова В. Ю. Соціокомунікативна адаптація як складова адаптації іноземних студентів до навчання в українській вищій школі / В.Ю.Стрельцова// Науковий вісник Донбасу. 2014. № 4. URL: http://nbuv.gov.ua/UJRN/nvd_2014_4_27 